\title{
Asesmen Logam berat Sampel Udara pada TSP di Sekitar PLTU Pacitan
}

\author{
Sri Murniasih a ${ }^{\text {a }}$, Kharistya Rozana a, ${ }^{\text {a }}$, Devi Swasti Prabasiwi ${ }^{\text {a }}$ \\ a Pusat Sains dan Teknologi Akselerator-BATAN \\ * corresponding author : kharistya.rozana@batan.go.id \\ DOI : $10.20885 /$ ijca.vol3 .iss 2 .art5
}

\section{ARTIKEL INFO}

Diterima : 04 Agustus 2020

Direvisi : 03 September 2020

Diterbitkan : 09 September 2020

Kata kunci : TSP, Logam Berat,

PLTU Pacitan, AAN

\begin{abstract}
ABSTRAK
Sampel Total Suspended Particulate (TSP) udara ambien di enam lokasi sampling di sekitar PLTU Pacitan telah dilakukan asesmen masing-masing kandungan logam beratnya. Tujuan dari penelitian ini adalah untuk menilai kualitas udara sehubungan dengan partikulat udara, kandungan logam berat (As, $\mathrm{Cd}, \mathrm{Cr}, \mathrm{Cu}, \mathrm{Sb}$ dan $\mathrm{Zn}$ ), dan metaloid ( $\mathrm{Mg}, \mathrm{V}, \mathrm{Al}, \mathrm{Mn}, \mathrm{Fe}, \mathrm{Co})$ pada TSP serta mempelajari tren polutan di sekitar PLTU. Sampel partikulat udara TSP dipreprasi dengan metode gravimetri dan identifikasi logam berat berbahaya (As, Cd, Cr, Cu, Sb, Zn), metaloid (Mg, V, Al, $\mathrm{Mn}, \mathrm{Fe}, \mathrm{Co}$ ) dengan menggunakan teknik analisis aktivasi neutron. Kandungan logam berat berbahaya dalam sampel filter TSP terendah As (arsen) dengan nilai rata-rata 0,349 $\pm 0,0400 \mathrm{ng} / \mathrm{m}^{3}$ dan konsentrasi terbesar adalah $\mathrm{Zn}$ (seng) dengan konsentrasi rata-rata $58,1 \pm 3,24 \mathrm{ng} / \mathrm{m}^{3}$, dibandingkan dengan standar kualitas udara primer standar ambang tahunan rata-rata yang ditetapkan oleh Uni Eropa maupun WHO untuk $\mathrm{Cr}$, As, dan $\mathrm{Cd}$ masing-masing adalah $2,5 \mathrm{ng} / \mathrm{m}^{3} ; 6 \mathrm{ng} / \mathrm{m}^{3}$; dan $5 \mathrm{ng} / \mathrm{m}^{3}$, sedangkan hasil penelitian ini masing-masing mempunyai konsentrasi $0,367 \mathrm{ng} / \mathrm{m}^{3} ; 0,349 \mathrm{ng} / \mathrm{m}^{3}$; dan $0,243 \mathrm{ng} / \mathrm{m}^{3}$. Hal ini menunjukkan logam berat diudara di sekitar PLTU Pacitan dalam batas masih terkendali dengan jarak sekitar 0,6 km sampai $3 \mathrm{~km}$ dari cerobong pembuangan gas hasil sisa pembakaran.
\end{abstract}

\begin{tabular}{|c|c|}
\hline ARTICLE INFO & $A B S T R A C T$ \\
\hline $\begin{array}{l}\text { Received :04 August } 2020 \\
\text { Revised : O3 Seotember } 2020 \\
\text { Published : O9 September } 2020 \\
\text { Keywords : TSP, Heavy Metal, } \\
\text { Pacitan Steam Power Plant, NAA }\end{array}$ & 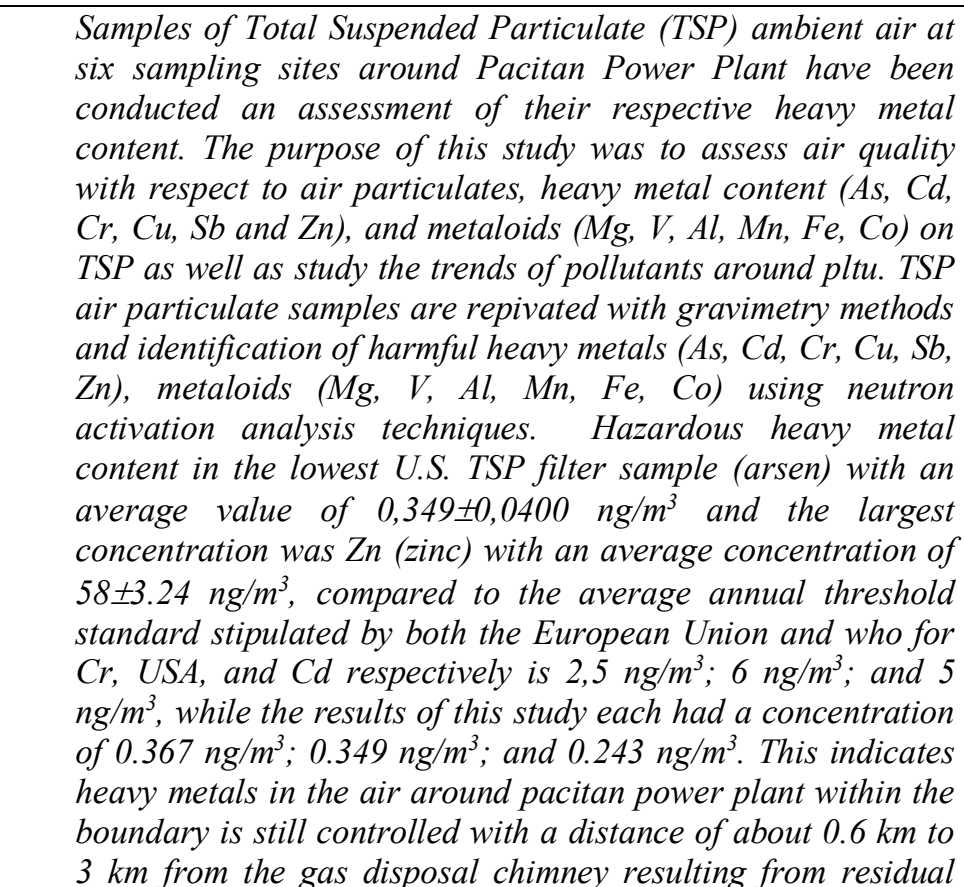 \\
\hline
\end{tabular}


combustion

\section{PENDAHULUAN}

Kualitas lingkungan yang baik merupakan syarat penting dalam keberlangsungan hidup setiap makhluk hidup. Udara sebagai komponen lingkungan yang penting dalam kehidupan perlu dilakukan peningkatan dan pemantauan kualitas serta pemeliharaan sehingga dapat memberikan dampak positif. Pencemaran atau polusi udara didefinisikan sebagai emisi antropogenik dari bahan kimia berbahaya yang mengubah komposisi kimiawi atmosfer alami dan memiliki efek buruk pada kesehatan makhluk hidup terutama manusia melalui konsumsi, kontak kulit dan paparan inhalasi, efek buruk pada antropogenik atau non-alami, struktur hidup atau mengurangi visibilitas udara [13]. Polutan udara adalah zat yang dipancarkan ke udara dari sumber antropogenik, biogenik atau geogenik yang bukan bagian dari atmosfer alami atau yang memiliki konsentrasi yang lebih tinggi di atmosfer alam dan dapat menyebabkan efek samping jangka pendek atau jangka panjang [4].

Salah satu pencemar udara berbahaya yang sering ditemukan adalah Total Suspended Particulate atau TSP. Total Suspended Particulate (TSP) adalah parameter penting yang berkontribusi terhadap penurunan kualitas udara. Pembentukan TSP dari permukaan tanah ke udara sekitar diduga dipengaruhi oleh sejumlah faktor yang terkait dengan kadar air tanah, angin yang bertiup, serta vegetasi yang menutupi permukaan tanah. Total Suspended Particulate (TSP) berupa campuran kompleks partikel padat, cair, atau keduanya di udara serta mengandung zat anorganik, organik dan partikel debu. TSP mempunyai diameter kurang dari $100 \mu \mathrm{m}$ [8-10] dan ada yang memiliki ukuran hingga sekitar $50 \mu \mathrm{m}$ [4]. Komposisi Particulate Matter (PM) udara sekitar kompleks dan berbeda tergantung pada sumber dan lokasi. Terjadinya logam berat beracun dalam fraksi Particulate Matter (PM) yang terhirup berkontribusi terhadap efek kesehatan yang substansial. Konsentrasi logam berat di udara ambien juga akan dipengaruhi oleh perubahan kondisi meteorologi $[13,14]$. Masalah polusi yang disebabkan oleh TSP merupakan masalah yang berbahaya bagi kehidupan manusia baik yang beraktivitas di dalam maupun di luar ruangan. TSP telah memicu berbagai penyakit seperti infeksi pernafasan dan juga gangguan pada penglihatan [46]. Menurut WHO, seseorang yang terpapar partikulat TSP dapat mengalami infeksi pernapasan akut (ISPA), asma, enfisema, kanker paru-paru, penyakit kardiovaskular, dan penyakit paru obstruktif kronis [7]. Sumber Particulate Matter (PM) dibagi menjadi dua yaitu bersifat alami dan antropogenik atau buatan. Sumber alami termasuk gunung berapi, kebakaran, badai debu, dan aerosol garam laut. Sumber Particulate Matter (PM) buatan manusia termasuk pembakaran dalam proses mekanik, proses pembakaran fosil, pembakaran biomassa, industri dan emisi kendaraan. $[9,11,12]$

Pembangkit Listrik Tenaga Panas adalah sumber utama pembangkit listrik untuk negara berkembang. Sekitar $60 \%$ pembangkit listrik di negara berkembang dipenuhi oleh pembangkit listrik termal [14]. Pembangkit listrik tenaga batu bara menghasilkan listrik untuk jaringan listrik nasional, tetapi mereka juga menghasilkan lebih banyak emisi udara berbahaya daripada sumber polusi industri lainnya. Secara global, pembangkit listrik tenaga panas berbahan bakar fosil menghasilkan sebagian besar emisi $\mathrm{CO}_{2}$ ke atmosfer. Emisi $\mathrm{CO}_{2}$ mengancam kesehatan orangorang yang tinggal di dekat pembangkit listrik ini, serta mereka yang tinggal dengan radius ratusan mil $[2,15]$.

Pabrik yang menggunakan pembakaran batu bara juga menghasilkan partikel halus. Partikelpartikel ini datang langsung dari abu dan jelaga, tetapi partikel yang lebih kecil berasal dari reaksi kimia yang dipancarkan gas di atmosfer. Partikel yang lebih kecil, yang dihasilkan oleh pembakaran bahan bakar fosil seperti pembangkit listrik tenaga batu bara, (atau dikenal sebagai partikel halus) memperburuk asma dan bronkitis, menyebabkan serangan jantung dan stroke, dan meningkatkan risiko kematian dini. Masalah kesehatan dari emisi pembangkit listrik dapat terjadi ketika levelnya tinggi dalam periode yang pendek atau pada level yang lebih rendah pada periode yang lebih lama [15].

Analisis polutan logam berat pada fiter TSP menggunakan metode analisis aktivasi neutron instrumental (AANI). Pilihan penggunaan AANI merupakan teknik analisis nuklir yang tidak merusak karena karakteristik analisisnya dapat dilacak dan tidak merubah bentuk fisik-kimia sampel. Metode AAN memanfaatkan fenomena tumbukan neutron terhadap unsur-unsur dalam 
bahan, sehingga unsur-unsur tersebut dalam kondisi tidak stabil (radioaktif). Untuk mencapai kembali keadaan stabil, unsur tersebut melepaskan partikel beta $(\beta)$ dan energi. Energi tersebut berupa sinar gamma yang bersifat karakteristik untuk setiap unsur, sehingga terbedakan antara satu unsur dengan unsur yang lain [12]. Selain itu sensitivitas yang tinggi dengan limit deteksi kecil ( $\mathrm{ppb}$ ) dan akurat, teknik AANI sangat cocok untuk analisis unsur kelumit dan ultra-trace metal pada analisis polutan logam berat di partikulat udara $[12,16]$.

Tujuan dari penelitian ini adalah untuk menilai kualitas udara sehubungan dengan partikulat udara, kandungan logam berat (As, $\mathrm{Cd}, \mathrm{Cr}, \mathrm{Cu}, \mathrm{Sb}$ dan $\mathrm{Zn}$ ), dan metaloid (Mg, V, Al, Mn, Fe, Co) pada TSP serta mempelajari tren polutan di sekitar PLTU Pacitan. Hasil penelitian ini dapat dimanfaatkan sebagai informasi kepada stakeholder terkait maupun masyarakat sekitar mengenai logam berat di sekitar PLTU Pacitan.

\section{METODE}

\subsection{Bahan dan alat yang digunakan}

Bahan yang dipergunakan pada penelitian ini yaitu masing-masing enam buah filter partikulat udara (TSP) merk millipore, filter blanko merk millipore, standar sekunder (standar tetes) dan standar primer SRM Urban Particulate Matter (UPM) merk NIST. Alat yang digunakan; High Volume Air Sampler (HVAS) merk SIBATA HV-1000R, dan alat-alat sampling lainnya, seperangkat alat Spektrometer Gamma $(\gamma)$ dengan detektor HPGe merk Ortec dengan perangkat lunak Maestro.

\subsection{Lokasi pengambilan sampel}

TABEL 1. Daerah dan koordinat geografis pengambilan sampel dengan jarak

\begin{tabular}{ccccc}
\hline Lokasi & Daerah & \multicolumn{2}{c}{ Koordinat geografis } & Jarak $(\mathrm{km})$ \\
\hline L-1 & Sumbereja & LS: $08^{\mathrm{O}} .15^{\prime} .22^{\prime}$ & BT: $111^{\mathrm{O}} .22^{\prime} .43 .6^{\prime}$ & 0,56 \\
L-2 & Sumbereja & LS: $08^{\mathrm{O}} .15^{\prime} .05,2^{\prime}$ & BT: $111^{\mathrm{O}} .22^{\prime} .58,8^{\prime}$ & 0,90 \\
L-3 & Kedungrejo & LS: $08^{\mathrm{O}} .15^{\prime} .24,7^{\prime}$ & BT: $111^{\mathrm{O}} .22^{\prime} .45,9^{\prime}$. & 1,10 \\
L-4 & Krajan & LS: $08^{\mathrm{O}} .15^{\prime} .22,0^{\prime}$ & BT: $111^{\mathrm{O}} .22^{\prime} .57,1^{\prime}$ & 0,90 \\
L-5 & Selang & LS: $08^{\mathrm{O}} .14^{\prime} .52,0^{\prime}$ & BT: $111^{\mathrm{O}} .33^{\prime} .31,0^{\prime}$ & 2,10 \\
L-6 & Kab. Trenggalek & LS: $08^{\mathrm{O}} .14^{\prime} .44,7^{\prime}$ & BT: $111^{\mathrm{O}} .24^{\prime} .05,7^{\prime}$ & 3,20 \\
\hline
\end{tabular}

Koordinasi lokasi sampel direkam menggunakan Global Positioning System (GPS). Koordinat geografis lokasi sampling dengan jarak cerobong PLTU Pacitan disajikan pada Tabel 1. Pengambilan sampel udara dilakukan di lima lokasi sampling Kecamatan Sidomoro Kabupaten Pacitan dan satu lokasi di perbatasan Kabupaten Trenggalek pada akhir Juli tahun 2016. Lokasi titik sampling disajikan pada Gambar 1. 


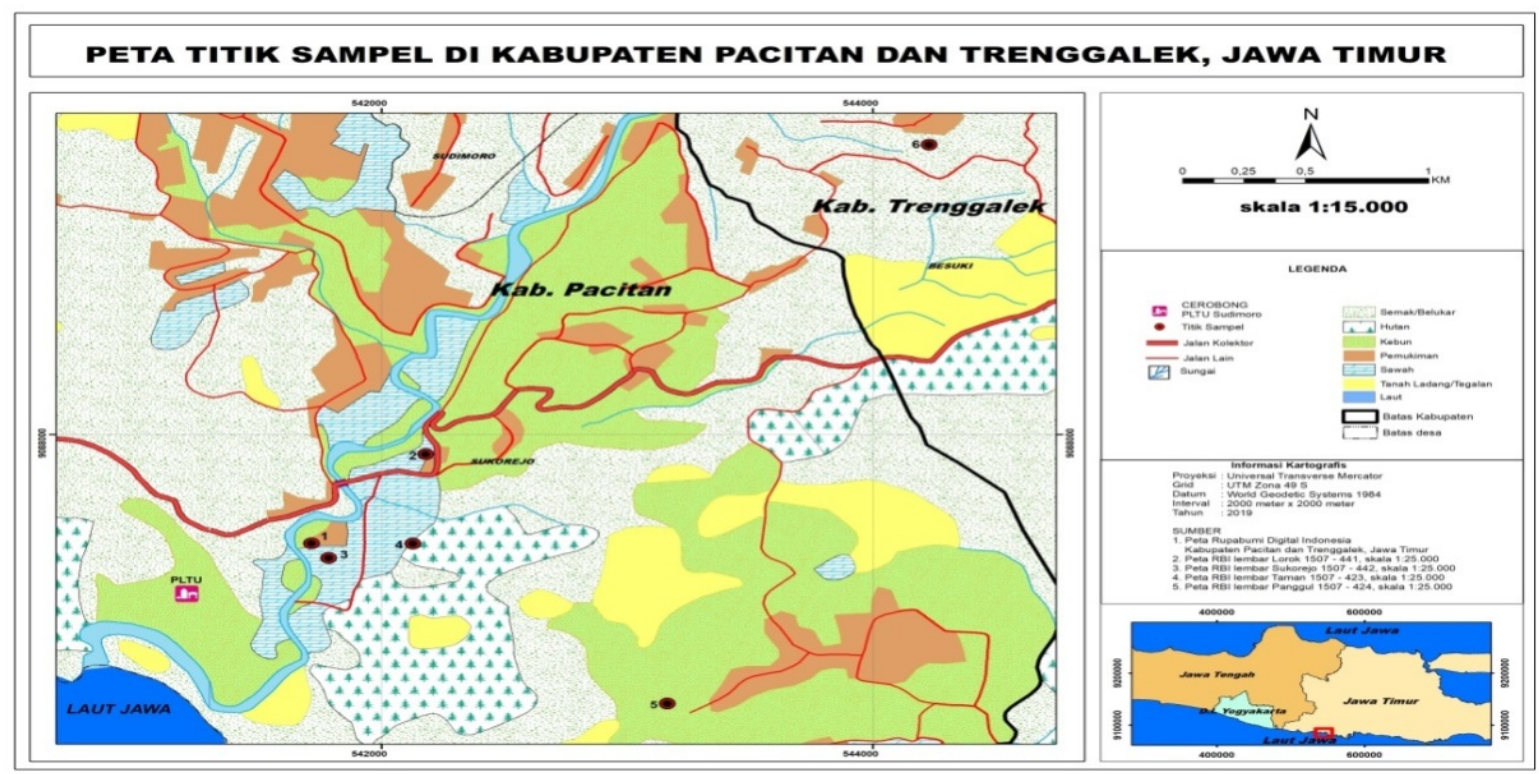

Gambar 1. Peta lokasi pengambilan sampel di sekitar PLTU Pacitan Jawa Timur

\subsection{Pengumpulan Sampel}

Particulate Matter (PM) diperoleh dengan memompa udara menggunakan alat High Voltage Air Sampler (HVAS) yang telah dilengkapi dengan kertas filter partikulat udara. Pengambilan sampel dilakukan selama 24 jam secara terus menerus sesuai acuan standar internasional [17,18]. Kertas filter partikulat udara yang telah dipreparasi dengan metode gravimetri kemudian disimpan dalam desikator selama 24 jam dan ditimbang berat sebelum dan sesudah pengambilan sampel [19]. Filter partikulat udara ditimbang tiga kali untuk mendapatkan berat yang konstan dan akurat. Penanganan filter partikulat udara dilakukan menggunakan sarung tangan vinil untuk menghindari kontaminasi. Setelah pengambilan sampel, kertas filter partikulat udara dimasukkan ke dalam desikator dan ditimbang untuk menentukan bobot akhir. Konsentrasi TSP di udara ditentukan dari perbedaan berat kertas saring setelah pengambilan $(\mathrm{Fe})$ dan sebelum pengambilan sampel $(\mathrm{Fc})$, massa bruto partikel di filter partikulat udara (Wg) dengan menggunakan persamaan (1) $[17,19,20]$.

$\mathrm{Wg}=\mathrm{Fe}-\mathrm{Fc}$

Sampel volume udara standar (Vstd) dalam $\mathrm{m}^{3}$ pada kondisi standar $\left(\mathrm{T}_{\text {std }}: 25{ }^{\circ} \mathrm{C}\right.$ dan $\mathrm{P}_{\text {std }}: 760$ $\mathrm{mmHg})$ [17]. Volume standar udara dipengruhi oleh volume aktual $\left(\mathrm{V}_{\text {act }}\right)$, tekanan udara sekitar aktual $\left(\mathrm{P}_{\mathrm{act}}\right)$ dan temperatur sekitar $\left(\mathrm{T}_{\mathrm{act}}\right)$. Volume standar udara ditentukan dengan persamaan (2).

$\mathrm{V}_{\text {std }}\left(\mathrm{m}^{3}\right)=\mathrm{V}_{\text {act }} \mathrm{x}\left(\mathrm{P}_{\text {act }} / \mathrm{P}_{\text {std }}\right)\left(\mathrm{T}_{\text {std }} / \mathrm{T}_{\text {act }}\right)$

Rata-rata temperatur dan tekanan pada sampling selama 24 jam sama dengan kondisi standar $\left(25{ }^{\circ} \mathrm{C} \& 760 \mathrm{mmHg}\right)$, maka persamaan (2) menjadi persamaan (3).

$\mathrm{V}_{\text {std }}\left(\mathrm{m}^{3}\right)=\mathrm{V}_{\text {act }}$

Konsentrasi TSP $\left(\mathrm{C}_{\mathrm{TSP}}\right)$ di udara ditentukan dengan persamaan (1) dan (3) yang ditunjukkan oleh Persamaan $(4)[4,17,20]$.

$$
C_{T S P}=\frac{W f-W i}{V s t d}
$$

\subsection{Analisis multi unsur pada sampel filter TSP}

Sampel filter TSP sebelum dan sesudah sampling ditimbang dimasukan wadah berlabel dan dimasukan dalam desikator, selanjutnya dilakukan penentuan kandungan logam berat berbahaya dan metaloid lainnya menggunakan metode AAN. Filter TSP dan blanko, diambil sebagian dan ditimbang sebanyak 0,200 g yang dimasukkan ke dalam vial polietilen. Sampel dimasukkan dalam kelongsong pneumatik untuk iradiasi unsur umur paruh pendek dengan. Iradiasi sampel untuk unsur umur menengah dan umur panjang, sampel dimasukkan ke dalam kelongsong iradiasi LDPE. Setiap kelongsong iradiasi LPDE berisi sampel PM, blanko filter, blanko standar, standar primer dan sekunder.

Iradiasi unsur umur paruh pendek ( $\mathrm{Al}, \mathrm{Cu}, \mathrm{Mn}, \mathrm{Mg}$, dan $\mathrm{V})$ menggunakan fasilitas pneumatik dengan waktu iradiasi dan waktu tunda pengukuran masing-masing selama 5 menit. Iradiasi 
menengah dan panjang dilakukan pada fasilitas Lazy Suzan selama 3 x 6 jam. Pengukuran unsur umur paruh menengah $(\mathrm{Cd}$, dan $\mathrm{Sb})$ dilakukan 3-4 hari setelah reaktor shut down, sedangkan untuk umur paruh panjang (Co, As, Fe, Cr, dan $\mathrm{Zn}) 3$ minggu setelah reaktor shut down.

\section{HASIL PENELITIAN}

Hasil analisis sampel partikulat TSP di sekitar PLTU Pacitan dengan menggunakan teknik analisis aktivasi neutron menunjukkan adanya kandungan logam berat dan metaloid. Logam berat terkandung yaitu $\mathrm{As}, \mathrm{Cd}, \mathrm{Cr}, \mathrm{Cu}, \mathrm{Sb}$ dan $\mathrm{Zn}$ yang disajikan pada Tabel 1 . Logam berat ini menjadi perhatian khususnya pada polutan udara yang telah banyak dilakukan oleh beberapa peneliti karena efeknya terhadap kesehatan masyarakat $[1,3,21]$. Logam metalloid yang terkandung pada sampel partikulat TSP adalah kelompok logam metalloid (Mg, V, Al, Mn, Fe dan Co) yang disajikan pada Tabel 2. Konsentrasi logam berat berbahaya dan logam metalloid di udara ambien juga dipengaruhi oleh perubahan kondisi meteorologi [1,21, 13], suhu dan tekanan sekitar sampling [17].

Pada Tabel 2 disajikan kandungan logam berat yang terdapat dalam filter TSP. Informasi yang diperoleh dari hasil analisis kandungan logam berat dengan metode AAN ini menunjukkan persebaran kandungan logam berat pada enam titik lokasi sampling di daerah Pacitan yang diakibatkan adanya aktivitas pencemaran PLTU Pacitan. Konsentrasi logam berat terkecil adalah logam berat As (arsen) dengan konsentrasi $(0,0250 \pm 0,00200-1,53 \pm 0,200) \mathrm{ng} / \mathrm{m}^{3}$ yaitu konsentrasi rata-rata di lokasi 5 (L-5) daerah Selang dan mempunyai konsentrasi rata-rata di enam lokasi $0,349 \pm 0,0400 \mathrm{ng} / \mathrm{m}^{3}$. Konsentrasi logam berat terbesar adalah logam berat $\mathrm{Zn}$ (seng) dengan konsentrasi $(10,6 \pm 0,360-113 \pm 3,45) \mathrm{ng} / \mathrm{m}^{3}$ yaitu konsentrasi terbesar di lokasi 3 daerah Kedungrejo dan mempunyai konsentrasi rata-rata $58,1 \pm 3,24 \mathrm{ng} / \mathrm{m}^{3}$. Dibandingkan dengan negara Arab Saudi pada daerah industri Rayes konsentrasi $\mathrm{Zn}$ dan $\mathrm{Cu}$ pada filter TSP masing-masing 180 dan $131 \mathrm{ng} / \mathrm{m}^{3}$ [21], negara Pakistan di daerah kota industri memiliki kandungan $\mathrm{Zn}$ dan $\mathrm{Cd}$ masing-masing 25,4 dan 32, $08 \mathrm{ng} / \mathrm{m}^{3}$ [20], dan negara Iran di daerah industri Taheran memiliki kandungan $\mathrm{Cr} 9,12 \mathrm{ng} / \mathrm{m}^{3}$ dan $\mathrm{Cd} 6,8 \mathrm{ng} / \mathrm{m}^{3}$ [22]. Senyawa arsenik banyak ditemukan baik dalam organik maupun anorganik di lingkungan. Konsentrasi arsenik di udara berkisar dari $1 \mathrm{ng} / \mathrm{m}^{3}$ hingga $10 \mathrm{ng} / \mathrm{m}^{3}$ di daerah pedesaan dan beberapa nanogram per meter kubik hingga sekitar 30 $\mathrm{ng} / \mathrm{m}^{3}$ di daerah perkotaan [23].

Standar ambang tahunan rata-rata yang ditetapkan oleh Uni Eropa dan WHO untuk Cr, As dan Cd masing-masing adalah $2,5 \mathrm{ng} / \mathrm{m}^{3} 6 \mathrm{ng} / \mathrm{m}^{3}, 5 \mathrm{ng} / \mathrm{m}^{3}$ [1,23]. Tabel 1 logam berat yang tersajikan merupakan logam berat dan berbahaya $(\mathrm{Cr}$, As dan $\mathrm{Cd})$ dengan nilai rata-rata masing masing adalah $(0,367 \pm 0,0200 ; 0,349 \pm 0,0400 ; 0,243 \pm 0,0300) \mathrm{ng} / \mathrm{m}^{3}$. Konsentrasi $\mathrm{Cr}$, As dan $\mathrm{Cd}$ dalam penelitian ini lebih rendah dari ambang batas konsentrasi rata-rata yang ditetapkan oleh Komisi Eropa dan WHO. Hal ini menunjukkan keberadaan PLTU Pacitan yang berjarak sekitar $(0,6-3,2)$ $\mathrm{km}$, hasil analisis logam berat berbahaya $\mathrm{Cr}$, As dan $\mathrm{Cd}$ tidak mempengaruhi kesehatan makhluk hidup dengan konsentrasi dibawah standar ambang batas maksimum. Akumulasi kandungan logam-logam berat dan berbahaya rata-rata yang ditemukan pada lokasi sekitar PLTU Pacitan disusun dalam urutan $\mathrm{Zn}>\mathrm{Cu}>\mathrm{Sb}>\mathrm{Cr}>\mathrm{As}>\mathrm{Cd}$.

TABEL II. Kandungan logam berat berbahaya dalam sampel filter TSP pada enam lokasi sampling di daerah Pacitan

\begin{tabular}{cccccccc}
\hline & \multicolumn{7}{c}{ Konsentrasi, $\mathrm{ng} / \mathrm{m}^{3}$} \\
\hline Logam & L-1 & L-2 & L-3 & L-4 & L-5 & L-6 & Rerata \\
\hline \multirow{2}{*}{$\mathrm{Zn}$} & $15,0 \pm$ & $10,6 \pm$ & $114 \pm$ & $73,1 \pm$ & $59,8 \pm$ & $76,2 \pm$ & $58,1 \pm$ \\
& 2,12 & 0,360 & 3,45 & 5,34 & 2,31 & 5,83 & 3,24 \\
$\mathrm{Cd}$ & $0,473 \pm$ & $0,301 \pm$ & $0,101 \pm$ & $0,0440 \pm$ & $0,401 \pm$ & $0,144 \pm$ & 0,243 \\
& 0,0600 & 0,0300 & 0,0100 & 0,00400 & 0,0500 & 0,0400 & $\pm 0,0300$ \\
& $0,118 \pm$ & $0,168 \pm$ & $0,137 \pm$ & $0,124 \pm$ & $1,53 \pm$ & $0,0250 \pm$ & $0,349 \pm$ \\
& 0,0100 & 0,00900 & 0,0500 & 0,0100 & 0,200 & 0,00200 & 0,0400 \\
& $2,41 \pm$ & $1,95 \pm$ & $0,893 \pm$ & $1,91 \pm$ & $0,0300 \pm$ & $1,30 \pm$ & $1,42 \pm$ \\
& & & \\
& 0,190 & 0,200 & 0,0700 & 0,200 & 0,00200 & 0,140 & 0,130
\end{tabular}




\begin{tabular}{|c|c|c|c|c|c|c|c|}
\hline $\mathrm{Cr}$ & $\begin{array}{l}0,403 \pm \\
0,0250\end{array}$ & $\begin{array}{l}0,106 \pm \\
0,0100\end{array}$ & $\begin{array}{l}0,319 \pm \\
0,0400\end{array}$ & $\begin{array}{l}0,332 \pm \\
0,0200\end{array}$ & $\begin{array}{l}0,335 \pm \\
0,0300\end{array}$ & $\begin{array}{l}0,412 \pm \\
0,0300\end{array}$ & $\begin{array}{l}0,367 \pm \\
0,0200\end{array}$ \\
\hline $\mathrm{Sb}$ & $\begin{array}{l}0,276 \pm \\
0,0300\end{array}$ & $\begin{array}{l}0,460 \pm \\
0,0300\end{array}$ & $\begin{array}{l}0,600 \pm \\
0,0800\end{array}$ & $\begin{array}{l}0,423 \pm \\
0,0500\end{array}$ & $\begin{array}{c}2,60 \pm \\
0,0500\end{array}$ & $\begin{array}{l}0,241 \pm \\
0,0100\end{array}$ & $\begin{array}{l}0,767 \pm \\
0,0400\end{array}$ \\
\hline
\end{tabular}

Tabel 3 disajikan kandungan logam metaloid ( $\mathrm{Mg}, \mathrm{V}, \mathrm{Al}, \mathrm{Mn}, \mathrm{Fe}$, dan $\mathrm{Co})$. Informasi yang diperoleh dari hasil analisis kandungan logam metaloid dengan metode AAN ini menunjukkan persebaran kandungan logam metaloid pada enam titik lokasi sampling di daerah Pacitan yang diakibatkan adanya aktivitas pencemaran PLTU Pacitan. Konsentrasi terbesar logam metaloid yang terdapat pada filter TSP adalah logam Al dengan konsentrasi 329 $\pm 9,01-906 \pm 19,8 \mathrm{ng} / \mathrm{m}^{3}$ dengan rata-rata konsentrasi $613 \pm 29,6 \mathrm{ng} / \mathrm{m}^{3}$ yang ditemukan pada lokasi 2 (daerah Sumbereja). Untuk konsentrasi logam Co terkecil terdapat di lokasi 2 (Sumbereja) yaitu 0,0400 $\pm 0,00100$ $0,440 \pm 0,0500 \mathrm{ng} / \mathrm{m}^{3}$ dengan konsentrasi rata-rata adalah $0,365 \pm 0,04 \mathrm{ng} / \mathrm{m}^{3}$. Logam metaloid $\mathrm{Mn}$, $\mathrm{V}$ dan Co memiliki konsentrasi yang kecil dibandingkan dengan konsentrasi logam metaloid $\mathrm{Al}, \mathrm{Fe}$ dan $\mathrm{Mg}$. Urutan tingkat konsentrasi rata-rata logam metaloid dari konsentrasi terbesar hingga terkecil $\left(\mathrm{ng} / \mathrm{m}^{3}\right)$ pada filter TSP adalah $\mathrm{Al}(613)>\mathrm{Fe}(295)>\mathrm{Mg}(186)>\mathrm{Mn}(1,85)>\mathrm{V}(0,524)>\mathrm{Co}$ $(0,365)$.

Evaluasi pemaparan tingkat latar belakang alamiah logam $\mathrm{V}$ di udara di Kanada telah dilaporkan pada kisaran $0,02-1,9 \mathrm{ng} / \mathrm{m}^{3}$ di daerah pedesaan sedangkan di daerah perkotaan berada pada konsentrasi $50 \mathrm{ng} / \mathrm{m}^{3}$ hingga $200 \mathrm{ng} / \mathrm{m}^{3}$. Paparan $\mathrm{Mg}$ di dekat sumber emisi, seperti industri ferro dan silico-mangan terkandung lebih dari $0,5 \mu \mathrm{g} / \mathrm{m}^{3}$, dengan konsentrasi paparan individu selama 24 jam kadang-kadang melebihi $10 \mu \mathrm{g} / \mathrm{m}^{3}$ [23]. Pada penelitian ini paparan tingkat konsentrasi logam V berkisar $(0,110-1,61) \mathrm{ng} / \mathrm{m}^{3}$ dengan konsentrasi rata-rata $0,524 \pm 0,0200$ $\mathrm{ng} / \mathrm{m}^{3}$ dan paparan konsentrasi rata-rata $\mathrm{Mg} 186 \pm 13,2 \mathrm{ng} / \mathrm{m}^{3}$. Selain itu, konsentrasi Mn rata-rata $1,85 \pm 0,0700 \mathrm{ng} / \mathrm{m}^{3}$ ditemukan lebih rendah dari pedoman kualitas udara Organisasi Kesehatan Dunia yaitu $150 \mathrm{ng} / \mathrm{m}^{3}$ [24]. Hal ini menunjukkan paparan metaloid logam V pada PLTU Pacitan merupakan paparan tingkat latar belakang alamiah, sedangkan $\mathrm{Mg}$ masih dibawah paparan konsentrasi perkotaan di Kanada yaitu $1,846 \pm 0,07 \mathrm{ng} / \mathrm{m}^{3}$.

TABEL III. Kandungan logam metaloid dalam sampel filter TSP pada berbagai tempat di daerah Pacitan

\begin{tabular}{cccccccc}
\hline \multicolumn{7}{c}{ Konsentrasi, $\mathrm{ng} / \mathrm{m}^{3}$} \\
\hline Logam & L-1 & L-2 & L-3 & L-4 & L-5 & L-6 & Rerata \\
\hline \multirow{2}{*}{$\mathrm{Mg}$} & $162 \pm$ & $268 \pm$ & $73,3 \pm$ & $281 \pm$ & $34,3 \pm$ & $299 \pm$ & $186 \pm$ \\
& 21,1 & 19,4 & 1,12 & 19,2 & 1,60 & 16,9 & 13,2 \\
$\mathrm{~V}$ & $0,118 \pm$ & $0,209 \pm$ & $0,114 \pm$ & $1,62 \pm$ & $0,158 \pm$ & $0,930 \pm$ & $0,524 \pm$ \\
& 0,00800 & 0,0100 & 0,0800 & 0,0200 & 0,0200 & 0,0100 & 0,0200 \\
$\mathrm{Al}$ & $870 \pm$ & $906 \pm$ & $523 \pm$ & $607 \pm$ & $329 \pm$ & $445 \pm$ & $613 \pm$ \\
& 91,0 & 19,8 & 9,00 & 14,3 & 9,01 & 34,7 & 29,6 \\
$\mathrm{Mn}$ & $1,92 \pm$ & $1,76 \pm$ & $1,48 \pm$ & $2,36 \pm$ & $0,174 \pm$ & $2,39 \pm$ & $1,85 \pm$ \\
& 0,00700 & 0,0700 & 0,0500 & 0,200 & 0,0200 & 0,0600 & 0,0700 \\
$\mathrm{Fe}$ & $253 \pm$ & $191 \pm$ & $373 \pm$ & $632 \pm$ & $188 \pm$ & $134 \pm$ & $295 \pm$ \\
& 20,5 & 20,0 & 54,0 & 11,9 & 27,3 & 11,2 & 24,2 \\
$\mathrm{Co}$ & $0,392 \pm$ & $0,0400 \pm$ & $0,300 \pm$ & $0,216 \pm$ & $0,440 \pm$ & $0,0780 \pm$ & $0,365 \pm$ \\
& 0,0200 & 0,00100 & 0,0300 & 0,0250 & 0,0500 & 0,00200 & 0,0600 \\
\hline
\end{tabular}

Dari ke 12 logam pada Tabel 2 dan 3, untuk memudahkan perbandingan konsentrasi dibuat histogram yang disajikan pada Gambar 2 dan 3. Gambar 2 menggambarkan konsentrasi logam hasil analisis sampel partikulat TSP dengan tingkat terendah yaitu logam Co pada lokasi $2(0,0400$ $\left.\mathrm{ng} / \mathrm{m}^{3}\right)$ hingga tertinggi yaitu logam Sb pada lokasi $5\left(2,60 \mathrm{ng} / \mathrm{m}^{3}\right)$. Pada Gambar 2 terlihat bahwa konsentrasi rata-rata terendah adalah logam $\mathrm{Cd}$ dan yang tertinggi adalah logam $\mathrm{Mn}$. 


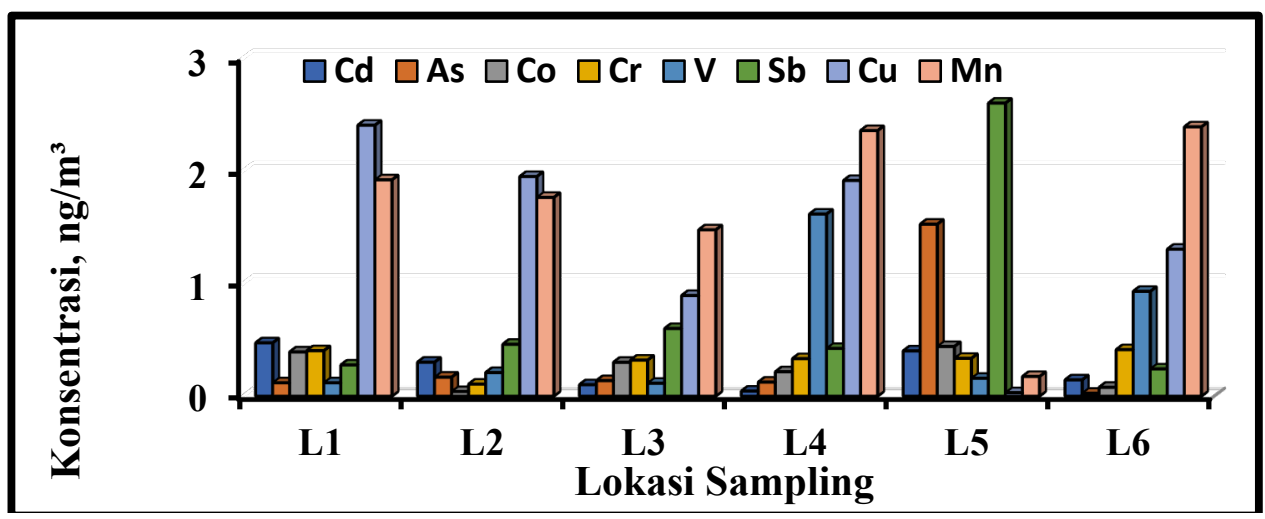

Gambar 2. Histogram konsentrasi logam hasil analisis dengan metode AAN waktu paruh pendek $(\mathrm{Cu}, \mathrm{V}$, dan $\mathrm{Mn})$, menengah (Cd dan $\mathrm{Sb})$, dan panjang (As, Co, dan $\mathrm{Cr}$ )

Gambar 3 merupakan konsentrasi histogram logam $\mathrm{Zn}, \mathrm{Mg}, \mathrm{Al}$ dan $\mathrm{Fe}$ dengan tingkat konsentrasi terendah 10,6 ng/ $\mathrm{m}^{3}$ untuk logam Zn lokasi 2 hingga $906 \mathrm{ng} / \mathrm{m}^{3}$ untuk logam Al lokasi 2. Logam-logam $\mathrm{Zn}, \mathrm{Mg}$, dan $\mathrm{Al}$ memiliki asal usul antropogenik. Logam $\mathrm{Fe}$ yang terdapat di udara memiliki konsentrasi tinggi bila dibandingkan dengan logam lainnya, selain itu logam $\mathrm{Fe}$ dapat berasal dari kerak, keausan rem dan ablasi muffler [24].

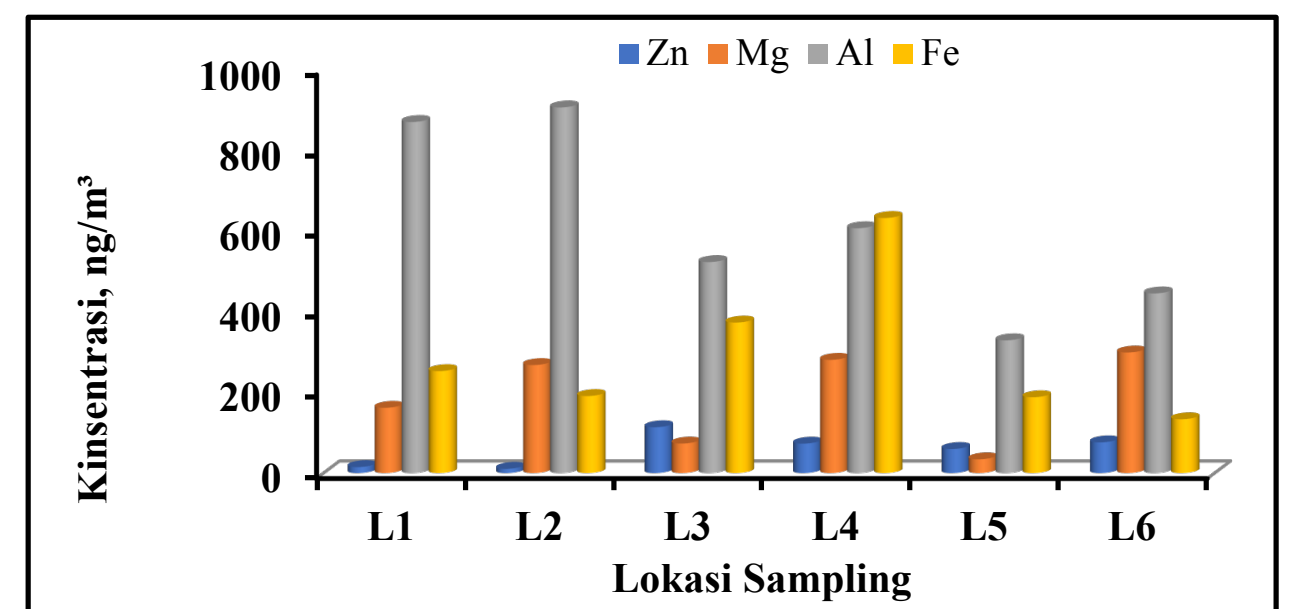

Gambar 3. Histogram konsentrasi logam hasil analisis dengan metode AAN waktu paruh pendek ( $\mathrm{Mg}$ dan $\mathrm{Al})$, dan panjang ( $\mathrm{Zn}$ dan $\mathrm{Fe})$

\section{KESIMPULAN}

Asesmen kualitas udara di sekitar PLTU Pacitan menunjukkan bahwa konsentrasi logam berat pada partikulat tersuspensi total (TSP) masih dibawah baku mutu Standar ambang tahunan rata-rata yang ditetapkan oleh Uni Eropa dan WHO. Akumulasi logam logam berat dan berbahaya rata-rata ditemukan dalam filter TSP berurut-turut adalah: $\mathrm{Zn}>\mathrm{Cu}>\mathrm{Sb}>\mathrm{Cr}>\mathrm{As}>\mathrm{Cd}$, sedangkan logam metaloid berturut turut adalah: $\mathrm{Al}>\mathrm{Fe}>\mathrm{Mg}>\mathrm{Mn}>\mathrm{V}>\mathrm{Co}$.

\section{Acknowledgment}

Penulis mengucapkan terima kasih kepada pemerintah melalui anggaran DIPA 2016 PSTA BATAN sehingga pengambilan sampel ini dapat terlaksana dan penelitian ini dapat terselesaikan pada tahun 2019. Penulis mengucapkan terima kasih kepada Bapak Sutanto Wisnu Wadhana yang telah membantu penelitian ini baik dalam sampling maupun preparasi dan kepada Bapak Sukirno sebagai penanggung jawab uspen yang telah banyak membantu dalam penyelesaian makalah ini. 
Penulis mengucapkan terima kasih kepada rekan-rekan bidang reaktor dalam membantu iradiasi sampel. Tak lupa, penulis juga mengucapkan terimakasih kami kepada Badan Kesatuan Bangsa dan Politik atas memberikan Rekomendasi Penelitian dan Rekomendasi Pengabdian Masyarakat dan Badan Pemerintah Perencanaan Pembangunan Penelitian dan Pengembangan Daerah - Pemerintah Kabupaten Pacitan, yang memberikan izin dalam pelaksanaan penelitian di wilayah Kecamatan Sidomoro dan PLTU Pacitan.

\section{Daftar Pustaka}

[1] Xiaofeng, Wang, et al, "Spatiotemporal characteristics and health risk assessment of heavy metals in PM 2.5 in Zhejiang Province,” Int. J. Environ. Res. Public Health., vol. 15, pp. 1-18, 2018

[2] S. Fuzzi1, "Particulate matter, air quality and climate: lessons learned and future needs." Atmos. Chem. Phys., vol. 15, pp. 8217-8299, 2015

[3] Xin Hua, et al, "Bioaccessibility and health risk of arsenic and heavy metals $(\mathrm{Cd}, \mathrm{Co}, \mathrm{Cr}, \mathrm{Cu}, \mathrm{Ni}, \mathrm{Pb}, \mathrm{Zn}$ and Mn) in TSP and PM2.5 in Nanjing, China," Atmospheric Environment., vol. 57, pp. 146-152, 2012

[4] I. P. S. Araujo, B. Dayana, D. B. Costa, R. J. B. de Moraes, "Identification and characterization of particulate matter concentrations at construction jobsites," Sustainability., vol. 6, pp. 7666-7688, 2014

[5] A. Mukherjee, M. Agrawal, "A Global perspective of fine particulate matter pollution and its health effects," Reviews of Environmental Contamination and Toxicology., vol. 244, pp. 5-52, 2017

[6] M. Haque, M. J. Ferdous, "Natural radionuclides present in air and water near nuclear research reactor Savar Bangladesh," International Journal of Scientific \& Engineering Research., vol. 8, pp. 978-983, 2017

[7] A. Gusti, R. A. Yurnal, Health risk assessment of total suspended particulate exposure to employee of PT Semen Padang, Indonesia, Iran J Public Health., vol. 48, pp. 1535-1536, 2019

[8] R. O. Esekhagbe, G. B. Onwumere, P. A, Vantsawa, "Evaluation of total suspended particles in ambient air of small scale industries in Kaduna Metropolis," International Journal of urrent Microbiology and Applied Sciences., vol. 5, pp. 36-41, 2016

[9] O. Jonathan, et al, "Clearing the air: a review of the effects of particulate matter air pollution on human health," J. Med. Toxicol., vol. 8, pp. 166-175, 2012

[10] A. S. Yuwono, et al, "Generation of total suspended particulate (TSP) in ambient air from four soil types in Indonesia," Journal of Applied Environmental Sciences, vol. 11, pp. 995-1006, 2016

[11] M. A. Awan, S. H. Ahmed, R. Aslam, and I. A. Qazi, "Determination of total suspended particulate matter and heavy metals in ambient air of four cities of Pakistan," Iranica Journal of Energy \& Environment., vol. 2, pp. 128-132, 2011

[12] Hamidatou, et al, "Concepts, instrumentation and techniques of neutron activation analysis," Licensee InTech Open, Algeria, 2019

[13] Byeong-Kyu Leea, Gee-Hyeong Parkb, "Characteristics of heavy metals in airborne particulate matter on misty andclear days," Journal of Hazardous Materials, vol. 184, pp. 406-418, 2010

[14] S. Kumar, D. Katoria, and D. H. Sehgal, "Environment impact assessment of thermal power plant for sustainable development," International Journal of Environmental Engineering and Management., vol. 4, pp. 567-572, 2013

[15] American Lung Association National Headquarters Offices, "Toxic Air: The Case for Cleaning Up Coal-fired Power Plants,” Washington, D.C., 2011

[16] R. Mejía-Cuero, et al, "Application of neutron activation analysis for determination of $\mathrm{As}, \mathrm{Cr}, \mathrm{Hg}$, and Se in mosses in the metropolitan area of the valley of Toluca Mexico," Hindawi Publishing Corporation Journal of Chemistry., vol. 13, pp. 1-13, 2015

[17] Masitah, Zaini, Hamzah, Lee, See, Kenn, "PM10 and total suspended particulates (TSP) measurements in various power stations," The Malaysian Journal of Analytical Sciences., vol. 11, pp. 255-261, 2007 
[18] B. S. Fakinle, et al, "Toxicity potential of particulates in air shed of haulage vehicle park," Global NEST Journal., vol. 15, pp. 466-473, 2013

[19] A. E. David, I. Z. Kesiye, U. A. Stephen, A. Nimibofa, B. A. Etta, "Measurement of total suspended particulate matter (TSP) in an urban environment: Yenagoa and its environs," Journal of Geography, Environment, and Earth Science International., vol. 11, pp. 1-8, 2017

[20] M. A. Awan, S. H. Ahmed, M. R. Aslam, I. A. Qazi, "Determination of total suspended particulate matter and heavy metals in ambient air of four cities of Pakistan," Iranica Journal of Energy \& Environment., vol. 2, pp. 128-132, 2011

[21] M. Jalal, Basahi, et al, "Total suspended particulate matter (TSP ) and its associated heavy metals in atmosphere on the Western Coast of Saudi Arabia,” Pol. J. Environ. Stud., vol. 26, pp. 2419-2424, 2017

[22] M. Leili, et al, "The study of TSP and PM10 concentration and their heavy metal content in central area of Tehran, Iran,” Air Qual Atmos Health., vol. 1, pp. 159-166, 2008

[23] World Health Organization, "World health organization regional office for Europe Copenhagen, air quality guidelines No. 91 for Europe $2^{\text {nd }}$ ed," WHO Regional Publications., European Series, Europe, 2000

[24] G. Safo-Adu, F. G. Ofosu, D. Carboo, Y. S. Armah, "Heavy metals and black carbon assessment of PM10 particulates along Accra-Tema highway in Ghana," International Journal of Science and Technology., vol. 3, pp. 467-474, 2014

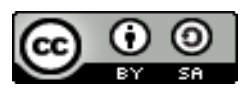

Jurnal IJCA is licensed under aÂ Creative Commons Attribution ShareAlike 4.0 